We thank the Poisons Information Centre at Guy's Hospital London, and Sandoz Products Limited, for their swift co-operation in the management of this case, and Dr J A Black for permission to report it.

\section{References}

1 Kenna A P. Accidental adminstration of Syntometrine to a newborn infant. BrJ Obstet Gynaecol 1972; 79:764-6.

2 Brereton-Stiles G C, Winship W S, Goodwin N M, Roos R F. Letter: Accidental administration of Syntometrine to a neonate. $S$ Afr Med J 1972; 46: 2052.

3 Embrey M P, Barber D T C, Scudamore J H. Use of Syntometrine in prevention of post-partum haemorrhage. Br Med J 1963; 1 : 1387-9.
4 Schwartz R H, Jones R W A. (1978) Transplacental hyponatraemia due to oxytocin. Br Med J 1978; 1 : 152-3.

5 Vere M F, Sellers S M. Letter: Transplacental hyponatraemia due to oxytocin. $\mathrm{Br}$ Med J 1978; $1: 362$.

6 McIntosh N, Walters R O. Effect of tolazoline in severe hyaline membrane disease. Arch Dis Child 1979; 54: 105-10.

7 Abbott T R, Rees G J, Dickinson D, Reynolds G, Lord D. Sodium nitroprusside in idiopathic respiratory distress syndrome. $\mathrm{Br}$ Med J 1978; 1 : 1113-4.

Correspondence to Dr M F Whitfield, Subregional Neonatal Intensive Care Unit, Jessop Hospital for Women, Leavygreave Road, Sheffield S3 7RE.

\title{
Prostaglandin synthetase inhibitor in an infant with congenital chloride diarrhoea
}

\author{
ADRIAN M B MINFORD AND DAVID G D BARR
}

Royal Hospital for Sick Children, Edinburgh

SUMMARY Hyper-reninaemia, hypokaluria, and hypokalaemia in an infant with congenital chloride diarrhoea improved during treatment with a prostaglandin synthetase inhibitor, ketoprofen. There was evidence of increased activity of the renin-aldosterone system when ketoprofen was stopped. It is suggested that prostaglandins may be involved in stimulating the renin-aldosterone system in congenital chloride diarrhoea.

In congenital chloride diarrhoea, juxtaglomerular hyperplasia, hyper-reninaemia, and hyperaldosteronism (with normal blood pressure), leading to hyperkaluria and hypokalaemia, complicate and worsen electrolyte imbalance and may predispose to vascular damage and further nephropathy. ${ }^{8}$ These features are also present in Bartter's syndrome in which increased renal production of prostaglandins has been implicated and a favourable response to prostaglandin synthetase inhibitors described. ${ }^{1-3}$ The clinical and biochemical effects of the prostaglandin synthetase inhibitor, ketoprofen, are reported in an infant with congenital chloride diarrhoea.

\section{Case report}

A Nigerian boy of $2.42 \mathrm{~kg}$ was born at 33 weeks' gestation by normal delivery after a pregnancy complicated by hydramnios. At 12 hours he developed watery diarrhoea and abdominal distension. He became dehydrated and hyponatraemic (serum Na $119 \mathrm{mmol} / \mathrm{l}, \mathrm{K} 4 \cdot 3 \mathrm{mmol} / \mathrm{l}$, urea $10 \cdot 3$ $\mathrm{mmol} / 1 ; 62 \mathrm{mg} / 100 \mathrm{ml}$ ). He was given intravenous fluids and the diarrhoea settled after 2 weeks. Stool electrolytes were not estimated. After discharge at 4 weeks, abdominal distension persisted although he was gaining weight and had no apparent diarrhoea. However, at 4 months his weight had fallen $<3$ rd centile and, as serum $\mathrm{K}$ was $2.3 \mathrm{mmol} / \mathrm{l}$, oral $\mathrm{KCl}$ was started.

Two weeks later he was admitted to this hospital with bronchiolitis which settled within 3 days. His weight of $4.49 \mathrm{~kg}$ was $<3 \mathrm{rd}$ centile and he was mildly dehydrated. Shortly after admission watery diarrhoea was noted and this persisted. Gross abdominal distension was present. Blood pressure was $90 / 60$ mmHg. Serum electrolytes on admission were: $\mathrm{Na} 132, \mathrm{~K} 2 \cdot 9, \mathrm{Cl} 83 \mathrm{mmol} / \mathrm{l}$, and urea $7.6 \mathrm{mmol} / \mathrm{l}$ $(45 \cdot 8 \mathrm{mg} / 100 \mathrm{ml})$. Chloride was undetectable in the urine. Urinary $\mathrm{Na}$ was $6 \mathrm{mmol} / \mathrm{l}$ and urinary $\mathrm{K}$ $46 \mathrm{mmol} / 1$. Stool electrolytes were: $\mathrm{Na} 51, \mathrm{~K} \mathrm{39}$, and $\mathrm{Cl} 103 \mathrm{mmol} / \mathrm{l}$. $\mathrm{Hb}$ was $10 \cdot 3 \mathrm{~g} / \mathrm{dl}$ and WBC $13.7 \times 10^{9} / 1$. Reducing substances were absent from the stools and no pathogens were isolated on stool culture. The plasma renin concentration (1261 $\mu \mathrm{U} / \mathrm{ml}$ ) was greatly raised compared with the normal adult range for this laboratory of $9-52 \mu \mathrm{U} / \mathrm{ml}$. Plasma aldosterone of $21 \mathrm{ng} / 100 \mathrm{ml}(0.58 \mathrm{nmol} / \mathrm{l})$ 
was within the normal range $6-105 \mathrm{ng} / 100 \mathrm{ml}$ $(0 \cdot 166-2 \cdot 9 \mathrm{nmol} / \mathrm{l})$ for infants. ${ }^{4}$ Urinary prostaglandin $\mathrm{E}_{2}$ excretion of $329 \mathrm{ng} / 24 \mathrm{~h}$ was higher than values obtained from 3 control infants of the same age $(190,279$, and $280 \mathrm{ng} / 24 \mathrm{~h})$ and exceeded the normal adult range of $76-281 \mathrm{ng} / 24 \mathrm{~h} .^{2}$ Urinary prostaglandin $\mathrm{F}_{2} \alpha$ excretion was $2721 \mathrm{ng} / 24 \mathrm{~h}$ which, although exceeding the normal adult range of $422-871 \mathrm{ng} / 24 \mathrm{~h}$, was similar to control values of 1305,2728 , and $2780 \mathrm{ng} / 24$ hours.

Initially, our patient was given intravenous fluids with added $\mathrm{KCl}$. A week later oral feeding and oral $\mathrm{KCl}$ supplements $(21.6 \mathrm{mmol} \mathrm{K}$ per day) were started. Total daily fluid intake was $1600 \mathrm{ml}$. Four weeks after admission ketoprofen $10 \mathrm{mg}$ a day was started and a week later this was increased to $20 \mathrm{mg}$ a day. Changes in weight gain, serum and urinary potassium, plasma renin, and aldosterone concentrations are shown in Fig. 1. On ketoprofen $20 \mathrm{mg}$ a day, urinary $\mathrm{K}$ excretion fell and serum $\mathrm{K}$ increased.
This was accompanied by a fall in plasma renin and aldosterone concentrations to $281 \mu \mathrm{U} / \mathrm{ml}$ and $14 \mathrm{ng} / 100 \mathrm{ml}(0.38 \mathrm{nmol} / \mathrm{l})$ respectively. Serum electrolytes remained normal for 5 weeks after starting ketoprofen. He then became hypokalaemic for 5 days with a rise in urinary $K$ excretion and oral $\mathrm{KCl}$ supplements were increased. The effect of withdrawing prostaglandin synthetase inhibition was assessed by stopping ketoprofen after 10 weeks of treatment. Shortly afterwards, hypokalaemia with increased urinary loss of $\mathrm{K}$ necessitated a further increase in oral $\mathrm{KCl}$ supplements. Plasma renin and aldosterone concentrations increased to $348 \mu \mathrm{U} / \mathrm{ml}$ and $57 \mathrm{ng} / 100 \mathrm{ml}(1.58 \mathrm{nmol} / \mathrm{l})$ respectively. As the patient was then lost to further follow-up by us, ketoprofen was not restarted.

Changes in urinary prostaglandin excretion are shown in Fig. 2. On ketoprofen $20 \mathrm{mg}$ a day urinary $\mathrm{PgE}_{2}$ excretion fell from 558 to $123 \mathrm{ng} / 24 \mathrm{~h}$. After 5 weeks of treatment with ketoprofen, urinary $\mathrm{PgE}_{2}$
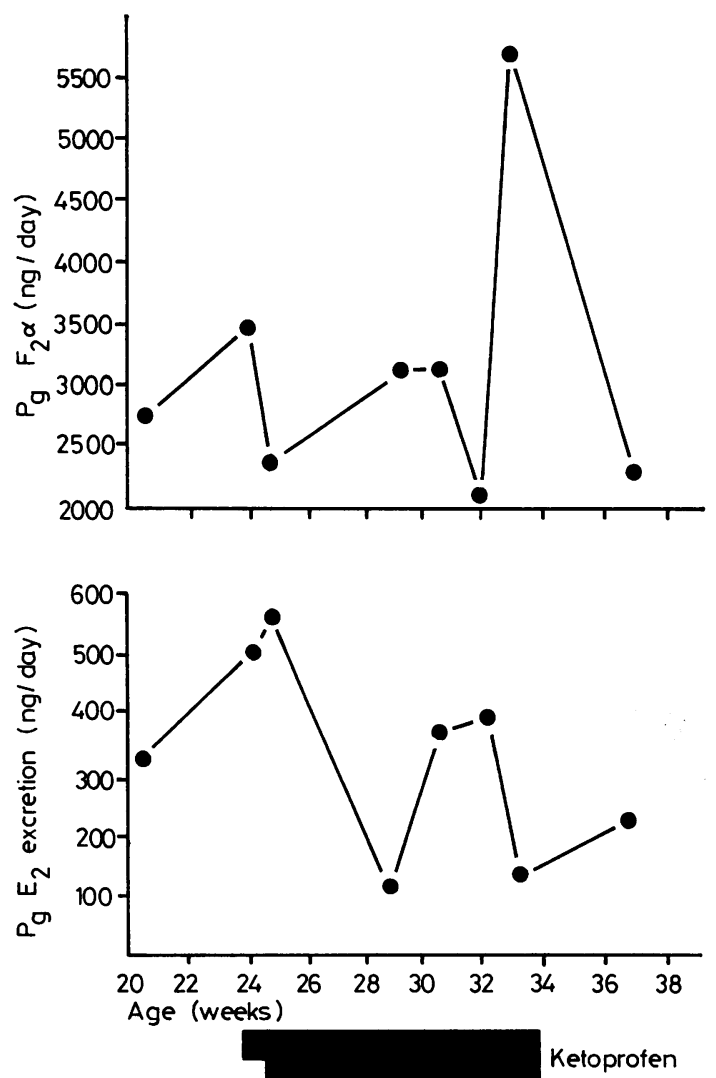

Fig. 2 Effect of ketoprofen on urinary excretion of prostaglandins $E_{2}$ and $F_{2} \alpha$
Conversion: 'SI to traditional units-aldosterone $1 \mathrm{pmol} / 1 \approx 0.036$ $\mathrm{ng} / 100 \mathrm{ml}$. 
excretion increased at a time when the infant was also hypokalaemic (Fig. 1). Urinary $\mathrm{PgE}_{2}$ excretion did not rise significantly when ketoprofen was stopped. Urinary $\mathrm{PgF}_{2} \alpha$ excretion was variable but did not seem to be affected by ketoprofen.

While on ketoprofen, watery diarrhoea, abdominal distension, and stool electrolyte concentrations remained substantially unchanged. The infant continued to gain weight after ketoprofen was stopped and serum potassium became normal on increased oral $\mathrm{KCl}$ supplements.

\section{Discussion}

The clinical features and the high faecal $\mathrm{Cl}$ exceeding the sum of $\mathrm{K}$ and $\mathrm{Na}$ concentrations confirm the diagnosis of congenital chloride diarrhoea in this infant.

Recently, the importance of controlling hyperreninaemia and hyperaldosteronism if renal and vascular changes are to be prevented has been emphasised. Holmberg et al. ${ }^{7-8}$ showed that while replacement with adequate fluids and $\mathrm{KCl}$ can improve the clinical state, increased aldosterone secretion persists. They found normal urinary aldosterone excretion in patients given both $\mathrm{NaCl}$ $\mathrm{KCl}$. They argue that without adequate $\mathrm{NaCl}$ replacement a normal body sodium content is maintained only by increased aldosterone activity.

Initially, our patient had pronounced hyperreninaemia (Fig. 1). The plasma aldosterone concentration at this time was however not raised, and this may have been due to the effects of chronic hypokalaemia which is known to suppress aldosterone secretion. ${ }^{5}$ The pronounced fall in plasma renin concentration after starting ketoprofen may partly have been due to correction of chronic dehydration but continuing lower plasma renin and aldosterone levels were found during treatment with ketoprofen and on stopping treatment there was a pronounced increase in both levels. Suppression of renin and aldosterone activity while on a prostaglandin synthetase inhibitor, and increase in activity on stopping ketoprofen, suggests that prostaglandins may have affected the stimulation of the reninaldosterone system. It might be argued that natural fluctuations were responsible for these differences in renin-aldosterone activity. However, there was no change in diarrhoea or abdominal distension regardless of whether the patient was on or off ketoprofen. Stool electrolyte concentrations remained unchanged while taking ketoprofen. While urinary $\mathrm{PgF}_{2} \alpha$ seemed unaffected by ketoprofen, $\mathrm{PgE}_{2}$ excretion fell from pretreatment levels that were higher than controls. Varying degrees of prostaglandin synthetase inhibition may have been responsible for fluctuations in urinary $\mathrm{PgE}_{2}$ excretion, accompanied by the variations in levels of serum and urinary potassium which occurred after the first 5 weeks of treatment. In congenital chloride diarrhoea, hyper-reninism and hyperaldosteronism are thought to be a consequence of hypoelectroytaemia caused by intestinal loss of electrolytes. It may be that renal prostaglandins play an intermediate role in this process.

Ketoprofen is less toxic than other prostaglandin synthetase inhibitors, such as indomethacin, ${ }^{6}$ and our patient suffered no obvious toxic effects from its use. Ketoprofen may be an alternative to additional oral sodium chloride in suppressing hyperaldosteronism in congenital chloride diarrhoea, but further studies are needed to assess its effectiveness and provide guidelines on the duration of treatment and optimum dosage.

We are indebted to Dr R Kelly, MRC Reproductive Biology Unit, Edinburgh for prostaglandin assays, and to Dr Brown, Dr Leckie, and Dr Fraser, MRC Blood Pressure Unit, Western Infirmary, Glasgow, for renin and aldosterone measurements.

\section{References}

1 Fichman M P, Telfer N, Zia P, Speckart P, Golub M, Rude R. Role of prostaglandins in pathogenesis of Bartter's syndrome. Am J Med 1976; 60: 785-97.

2 Gill J R, Frölich J C, Bowden R E, et al. Bartter's syndrome: a disorder characterised by high urinary prostaglandins and a dependence of hyperreninemia on prostaglandin synthesis. Am J Med 1976; 61 : 43-51.

3 Littlewood J M, Lee M R, Meadow S R. Treatment of Bartter's syndrome in early childhood with prostaglandin synthetase inhibitors. Arch Dis Child 1978; 53: 43-8.

4 Dillon M J, Ryness J M. Plasma renin activity and aldosterone concentration in children. Br Med J 1975; 4: 316-9.

${ }^{5}$ Siegler R L, Crouch R H, Hackett T N, Walker M, Jubiz $W$. Potassium-renin-aldosterone relationships during the first year of life. J Pediatr 1977; 91 : 52-5.

6 Fossgreen J, Kirchkeiner B, Peterson O E, Tophoj E, Zachariae E. Clinical evaluation of ketoprofen (19583 RP) in rheumatoid arthritis. Double blind crossover trial against indomethacin. In: Dixon A St J, Duizabo P, Holt P J L, Jayson M I V, Wood P H N, eds. XIII Interational Congress of Rheumatology, Kyoto, 30 September6 October 1973 (abstracts). International Congress Series. Amsterdam: Elsevier/Excerpta Medica/North-Holland, 1973.

7 Holmberg C, Perheentupa J, Launiala K, Hallman N. Congenital chloride diarrhoea. Clinical analysis of 21 Finnish patients. Arch Dis Child 1977; 52: 255-67.

8 Holmberg C, Perheentupa J, Pasternack A. The renal lesion in congenital chloride diarrhea. $J$ Pediatr 1977; 91: $738-43$.

Correspondence to Dr A M B Minford, St James's Hospital, Department of Paediatrics, Leeds LS9 7TF. 